\title{
Uma experiência de intervenção performática em busca de outra "narrativa" para o ensino da arte
}

\author{
Georgina Furtado Franca'
}

\begin{abstract}
Resumo
Este artigo é parte de uma pesquisa de doutorado em Educação Artística da Faculdade de Belas Artes da Universidade do Porto, Portugal, a qual é desenvolvida no Brasil na cidade de João Pessoa no estado da Paraíba em um Centro Cultural composto de dois museus e em uma escola pública municipal. A investigação busca construir um novo entendimento sobre as possibilidades de experenciar o patrimônio a partir de um ato criativo de intervenção performática nos museus e que quando levado à escola propõe um saber ver diferenciado, multissensorial, dando a cada um dos sujeitos, a partir de suas interpretações e construções subjetivas, o apoderamento sobre o que está aprendendo, e assim, do sentido dado ao seu aprendizado, construir conhecimento. Fundamenta-se no conceito de narrativa desenvolvido por Walter Benjamin e tem como estratégia metodológica a autoetnografia. Uma aproximação com a cultura visual na prática de uma pesquisa educacional baseada em arte $A / r /$ tografia, em que conta-se uma história possibilitando aos outros contar a sua.

Palavras-chave

intervenção performática, narrativa, cultura visual, artografia, educação artística.
\end{abstract}

\begin{abstract}
This article form a part of doctorate research of Artistic Education in Faculty of Fine Arts of University of Porto, Portugal and that's developed in Brasil in João Pessoa, Paraíba's state in a Cultural Center composed of two museum and in a municipal public school. The investigation search to construct an another comprehension about the possibilities to experiment the patrimony as from an creative act of performance intervention in the museum and when takes to school search to promote a distinguished knowledge to see, sensorial multiple, offering to everyone as from their interpretation and subjective construct, the possession about that he is learning, so on, make sense about their learn, built knowledge. It's lay the foundation in concept of narrative developed for Walter Benjamin and have the autoethnography as research method. An approximation with a visual culture in a practice of an education research based in art, $A / r /$ tography, in which tell a tale to make possible another tell their tale too.
\end{abstract}

Keywords

performance intervention, narrative, visual culture, artography, artistic education.

\section{Introdução}

Este é um trabalho autoetnográfico, fruto de investigação de doutorado em Educação Artística da Faculdade de Belas Artes da Universidade do Porto em Portugal e que segue os princípios de uma Pesquisa Educacional Baseada em Arte - A/r/tografia. Neste trabalho, as ideias a serem discutidas serão então impulsionadas a partir da combinação entre textos e imagens que ao tempo que vão desvelando os problemas e as questões inerentes à investigação irão promovendo aberturas para novas leituras e interpretações. 
Como uma Pesquisa Viva (IRWIN, 2013, p.30) por se tratar de um processo relacional, de intervenção e criativo entre sujeitos, artefatos artísticos e visualidades do espaço público, esta pesquisa entra em conexão com as vozes de todos os colaboradores da pesquisa e desmembra-se na construção de novos contextos e sentidos sobre o mundo a partir dos valores socioculturais de cada um e daqueles que passam a ser construídos mutualmente ao longo do processo investigativo.

A pesquisa teve inicio em um Centro Cultural e se prolongou até a escola levando consigo as imagens do acervo e uma dramaturgia híbrida que chamamos de Narrativa. Os participantes da prática de investigação são cinco atores incluindo a mim como pesquisadora e vinte e quatro alunos de uma escola pública municipal, os quais vinte e um deles são alunos do 70 ano do ensino fundamental e três deles, alunos do $8^{\circ}$ ano do ensino fundamental.

O interesse de investigação doutoral originou-se do desejo de realizar uma experiência de intervenção performática em um museu cujo ato criativo e pedagógico pudesse gerar novas leituras do seu acervo e patrimônio levando a outros entendimentos e possibilidades para o ensino da arte na escola. Uma possibilidade de promover uma educação artística que fosse além do aprimoramento técnico, tendo os sujeitos e seus contextos sociais e culturais como elementos fundamentais no processo de ensinoaprendizagem.

Teoricamente o nosso trabalho fundamenta-se no conceito de narrativa desenvolvido por Walter Benjamim (1992), que considera a narrativa uma história incorporada de experiências, que inclui tanto o narrador quanto os seus ouvintes. Ao contrário de uma informação que deva ser passada de uma pessoa a outra e que se mantem viva apenas no momento em que é dada, a narrativa tem a capacidade de desenvolver-se e transformar-se (BENJAMIM, 1992).

A origem da narrativa advém de seus representantes arcaicos: o camponês ou mestre sedentário, o marinheiro comerciante ou aprendiz migrante e o artífice. Este último associava o saber das terras distantes trazidos pelos migrantes ao saber do passado do trabalhador sedentário para assim tecer as suas histórias. Uma forma artesanal de aprendizado e de comunicação que fazia das experiências individuais materiais para o desenvolvimento da história contada por outros e que por sua vez acrescentavam à mesma história as suas próprias experiências e assim por diante. Estas histórias se interpenetravam e iam originando uma forma de aprender em que o conteúdo nascia da 
vida, das experiências que ao longo do desenrolar da construção da história de cada um, ia se tornando uma experiência coletiva. (BENJAMIM, 1992).

A narrativa então a partir dos seus representantes arcaicos ia se elaborando de um processo de superposição de várias camadas constituídas pelas narrações sucessivas e que se interpenetravam, onde o fim da história não significava um ponto final, mas apenas uma sugestão de continuação da mesma. O seu conteúdo didático foi sendo constituído dos conceitos que puderam ser elaborados das múltiplas experiências e estratificados ao longo das várias gerações de artesãos, seja no campo, no mar ou na cidade e assim o narrador foi figurando-se entre os mestres e os sábios como aquele que sabe dar conselhos (BENJAMIM, 1992).

Como um artesão que capturando certo nível do sensível vai interagindo a alma, ao olho e a mão e definindo sua prática (BENJAMIM, 1992, p.20), a narrativa não se reduz em seu aspecto sensível a um produto exclusivo da voz, pois esta se faz também do corpo, das ações e dos gestos que podem tornar-se palavras e de palavras que da ausência ou invisibilidade na presença-ausência podem tornar-se gesto. Como uma rede cujos fios são relatos sucessivos e que podem transformar-se em uma escada que desce até o centro da terra e se perder nas nuvens (BENJAMIM, 1992, p.16), a narrativa vai se constituindo do entremeado de experiências que ao longo da sua construção vai tornando-se uma experiência coletiva (BENJAMIM, 1992).

Trazendo este conceito para a nossa investigação e reelaborando-o como proposta para o ensino da arte, a narrativa amalgama as experiências individuais e coletivas de alunos e professores na troca com o espaço público para construção de uma história ao mesmo tempo performática e literária.

Destacamos abaixo as etapas da investigação que correspondem à construção narrativa:

1) Seleciona-se visualmente elementos materiais e/ou imateriais do espaço público como trabalhos artísticos, pinturas, esculturas, fotografias, acontecimentos, que possam servir como propulsores para a escrita de uma frase chamada "frase geradora" a partir de um desses elementos selecionados.

2) Escreve-se a "frase geradora" a partir dos sentimentos eclodidos ou de memórias e lembranças pessoais mobilizadas do contato visual com os elementos anteriores selecionados do item1 acima. Se a imagem falasse o que ela diria? Este é um mote que impulsiona o ato da escrita da "frase geradora". 
3) Improvisam-se cenas performáticas a partir da combinação das "frases geradoras" elaborando-se frases corporais que se inter-relacionam na construção de uma história.

4) Debate-se criticamente sobre as cenas performáticas buscando construir conceitos e elaborando os contextos e sentidos da história a partir das subjetividades dos sujeitos envolvidos.

5) Elaboram-se relatos escritos e orais a partir das cenas performáticas buscando elaborar o enredo da história.

6) Realiza-se as cenas performáticas em espaço público, o que chamamos de intervenção performática, para seleção de outros elementos narrativos originários das inter-relações entre os sujeitos, o espaço e os seus públicos.

7) Passa-se a executar novamente os procedimentos dos itens 2 a 6 até a construção do enredo da história.

Ao longo deste processo simbiótico para construção da história envolvendo a visualidade, a escrita, a improvisação, a oralidade e a intervenção performática a partir de camadas de experiência que se inter-relacionam e se interpenetram a narrativa vai sendo construída e assumindo ao longo do processo de construção, papel educativo e pedagógico. Por sua natureza dialética, constituída de diálogos que conduzem as ações dos personagens, a narrativa vai se constituindo em uma proposta dramatúrgica híbrida para o ensino da arte, uma literatura diferente, que chamamos de Narrativa.

E é então da busca por construir conhecimentos a partir das inter-relações entre os sujeitos envolvidos, imersos nos problemas, potencialidades e impossibilidades do processo interativo e criativo com o espaço público que se vai desenvolvendo a problemática da pesquisa: Como fazer de uma dramaturgia e sua construção, imersa no espaço público, das relações estabelecidas política, socialmente e culturalmente entre os sujeitos e o espaço, outra possibilidade para o ensino da arte, com conteúdos próprios para serem trabalhados em processo de ensino-aprendizagem?

E é da escritura e não do texto, ou de uma linguagem em específico, que a Narrativa se dá, construída do intercambio de camadas sucessivas de experiências que se interpenetram para construção de uma história feita de ações e diálogos, uma dramaturgia. Ela nasce com o jogo que reúne os aspectos sensíveis da escrita, da oralidade, da visualidade e da performance, quando postos em relação para construção de uma história, em oposição à linguagem cuja comunicação se dá pela transmissão de uma mensagem que pode ser decodificada e passada de uma pessoa a outra como uma verdade a ser seguida (DERRIDA, 1999). 
A partir do entrelaçamento de camadas de experiências sucessivas e dando prosseguimento ao processo dramatúrgico a partir de conteúdos construídos ao longo da investigação, os alunos vão juntamente com seu professor a partir da construção narrativa buscando preencher os vazios da história de sentidos, construindo conceitos e compondo os chamados "temas geradores" de cada uma das cenas. Estes por sua vez originarão os conteúdos que chamamos de "debates narrativos" e que são mobilizadores de reflexões críticas sobre o processo dramatúrgico e de ensino-aprendizagem realizado. Um processo realizado de maneira compartilhada entre alunos e seus professores, buscando dissolver certa ordem explicadora que tende a criar dicotomias entre aquele que ensina e aquele que aprende, entre o saber e a ignorância (RANCIÈRE, 2010).

Construindo os sentidos da história a partir das suas subjetividades, dos valores socioculturais em relação e das interações com o espaço público, o aluno vai dando sentido ao seu próprio aprendizado, se apoderando do que está aprendendo, e revendo e construindo seus próprios conceitos sobre o mundo a partir da construção dramatúrgica. Uma forma de leitura de mundo que não se fecha em si mesma, mas que está sempre sendo posta em causa e em jogo como um gesto transgressor e de transformação.

Para Agamben (2007), este gesto, esta subjetividade, seria uma presença invisível cuja forma-de-vida apareceria justamente naquilo que a silencia, em um lugar vazio.

Em nossa investigação a metáfora do gesto torna-se uma atitude transgressora de resistência ao livro como propositor e metáfora do conhecimento hegemônico e uma busca por reconstruí-lo e reescrevê-lo para além das palavras ou da concepção do conhecimento ou da literatura como linguagem ou mensagem a ser decodificada. Mas pela construção de uma literatura diferente que pode tornar-se acontecimento. Uma busca por fazer ver o invisível, como se um gesto fosse e que além de conter o que trazemos em cada um de nós e do que somos, tenha a capacidade de transformar-se em atitude coletiva.

O livro e o gesto são metáforas, o livro metáfora de todo pensamento hegemônico que pode ser passado ao aluno como se fossem informações prontas para serem absorvidas como detentoras de uma verdade. E o gesto a subversão deste poder a partir da subjetividade do aluno, dos aspectos sociais, culturais e políticos dos quais e nos quais ele faz parte e que são postos em relação a partir da construção dramatúrgica. É preciso então entender que os livros e o fenômeno artístico precisam ser repensados não como linguagens fechadas em si mesmas, mas como escritura, pois assim dos livros nascerá o gesto e do gesto nascerá o livro e não fenecerá ou se fechará em si mesmo. 
Neste artigo, o que propomos a partir deste momento da escrita é que a mesma seja entrelaçada e que possibilite ao leitor elaborar conexões e interpretações sobre a investigação a partir do entremear de ideias, textos e imagens, personagens e atores, artefatos artísticos e questões postas em debate. Nas fotos os nomes são fictícios e as frases e textos se localizam no limiar entre o real e o fictício, ora por serem imagens do dia-a-dia de fatos experienciados pelos atores nos acervos do Centro Cultural, ora por serem na escola pelos estudantes e/ou por serem contextos vivenciados pelos personagens dentro da Narrativa.

Este artigo daqui por diante está dividido em três partes intituladas: I - Da Construção do Objeto - "À Uma arte que se entrega"; II - A Experiência e o Processo Narrativo e III - O Caminho Metodológico. Na primeira parte do artigo, é dada ênfase a aspectos que envolvem a construção e delimitação do objeto de pesquisa, a Narrativa, a partir dos problemas e restrições encontradas nos museus do Centro Cultural. A Narrativa, portanto vai-se constituindo como forma de resistência aos padrões hegemônicos e de relações de poder da instituição, que faz dos trabalhos artísticos em seu contato com os públicos dos museus a partir da exposição realizada pelos guias, um processo unilateral de transmissão de informações e não de construção de conhecimento.

Sendo assim, nesta parte do trabalho, vamos questionando a hegemonização da arte, a sua canonização, que faz a mesma tornar-se prisioneira de si mesma e por outro lado, vamos dando destaque a partir da Narrativa às ações e ideias que primam pelo protagonismo social, por uma arte que se entrega, a partir dos processos de subjetivação e interpretação, em uma proposta de educação artística que indo além dos aspectos formais e técnicos, faz dos sujeitos e seus contextos, protagonistas do processo de ensino- aprendizagem. Uma aproximação com a cultura visual que questionando a arte culta e sua desconstrução em ato criativo valoriza as formas das artes populares.

$\mathrm{Na}$ segunda parte do artigo, vai-se tecendo reflexões a respeito do processo de construção da Narrativa, uma escrita híbrida, feita do inter-relacionamento entre o teatro, as artes visuais e a literatura e que vai também surgindo como possibilidade de colocar em causa o conhecimento hegemônico dos museus e da escola, impulsionando a construção de outro tipo de conhecimento derivado da experiência.

Algumas questões são postas em destaque nesta etapa do trabalho como: Quais conteúdos estão sendo trabalhados durante o processo de construção da Narrativa? E como utilizá-los para o ensino da arte? Fundamentando teoricamente a pesquisa a partir 
do conceito de narrativa desenvolvido por Walter Benjamim, vamos dando ênfase as principais características da Narrativa que perpassa os dois momentos da investigação, no Centro Cultural e na escola.

Na terceira parte do artigo, evidencia-se a busca pela escrita da tese que é ao mesmo tempo literária, visual e performática. São destacadas às características do processo narrativo que contribuem para a associação da pesquisa com os princípios norteadores da Investigação Baseada nas Artes, mas especificamente, Pesquisa Educacional Baseada em Arte: $A / r /$ tografia.

Nesta parte do artigo, são levantadas questões em meio às imagens expostas que fazem da busca pela escrita também uma busca para dar a cada um dos sujeitos o direito de se apoderar do que está aprendendo e do sentido dado ao seu aprendizado construir conhecimento. Como construir a partir de uma experiência de intervenção performática, uma Narrativa para o ensino da arte? Desta, entre outras questões instiga-se a reflexão sobre outra possibilidade de educação artística para além da tradicionalmente aceita em nossas escolas, que dando voz ao aluno a partir de um saber ver diferenciado, pois sendo multissensorial, possa fazê-lo tornar-se protagonista da sua própria história.

\section{Da Construção do Objeto - "À Uma arte que se entrega"}

Para dar desenvolvimento a este artigo escolhi como base teórica inicial e para fundamentar esta primeira parte aqui discutida, a conferência proferida por Imanol Aguirre Arriaga em 2007 intitulada: Contenidos y Enfoques Metodológicos de La Educacion Artística, no Congresso de Formação Artística e Cultural para a Região da América Latina e do Caribe, promovida pela INSEA (Sociedade Internacional para Educação através da Arte). A partir desta, procuraremos estabelecer conexão com as demais referências teóricas do trabalho e tecer associações entre as ideias que se comunicam e se identificam com as da nossa pesquisa.

Partindo do entendimento de que não existem verdades absolutas ou fórmulas prontas para o desenvolvimento, construção e propagação do conhecimento; sendo o mesmo constituído de metáforas de linguagem que buscariam sua legitimação; confiamos à narratividade, à autorreflexão, o intercambio das experiências vivenciadas, o compromisso ético e político com o ofício, como uma forma genuína de pensar a arte na educação. Uma forma de resgatar o protagonismo social que as instituições educativas nos têm negado. Sendo assim, será como uma sucessão de contingencias que 
problematizaremos as questões da pesquisa e que estão no entrelaçar entre textos e imagens, tempos e espaços, falas e silêncios que seguem abaixo (AGUIRRE, 2007).

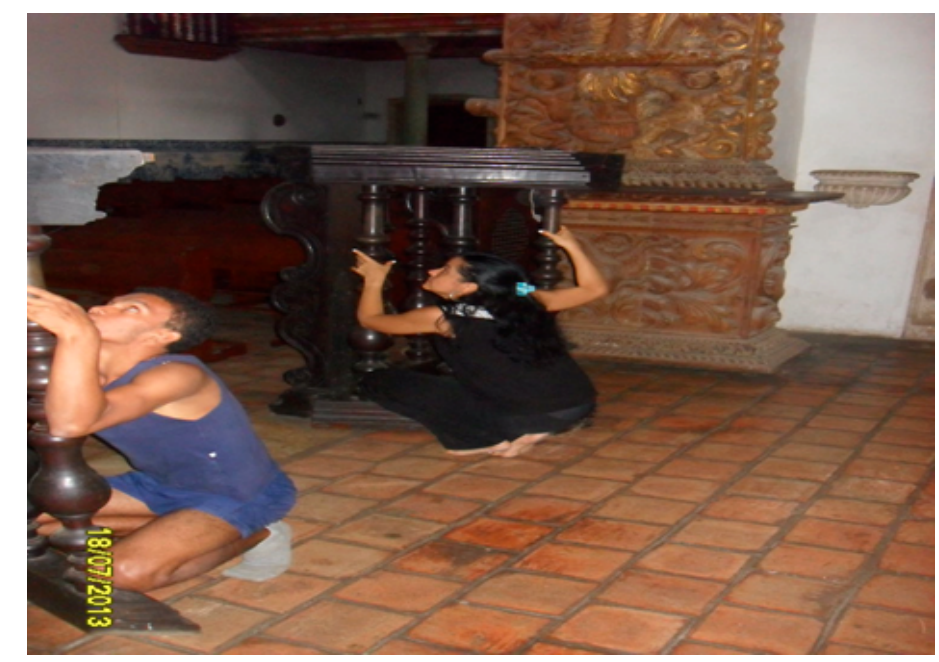

Figura 01 - Centro Cultural. Ano 2013. Fonte: Moisés de Pia. Miguel: Existe algo que me prende ao todo e eu não sei bem o que é.

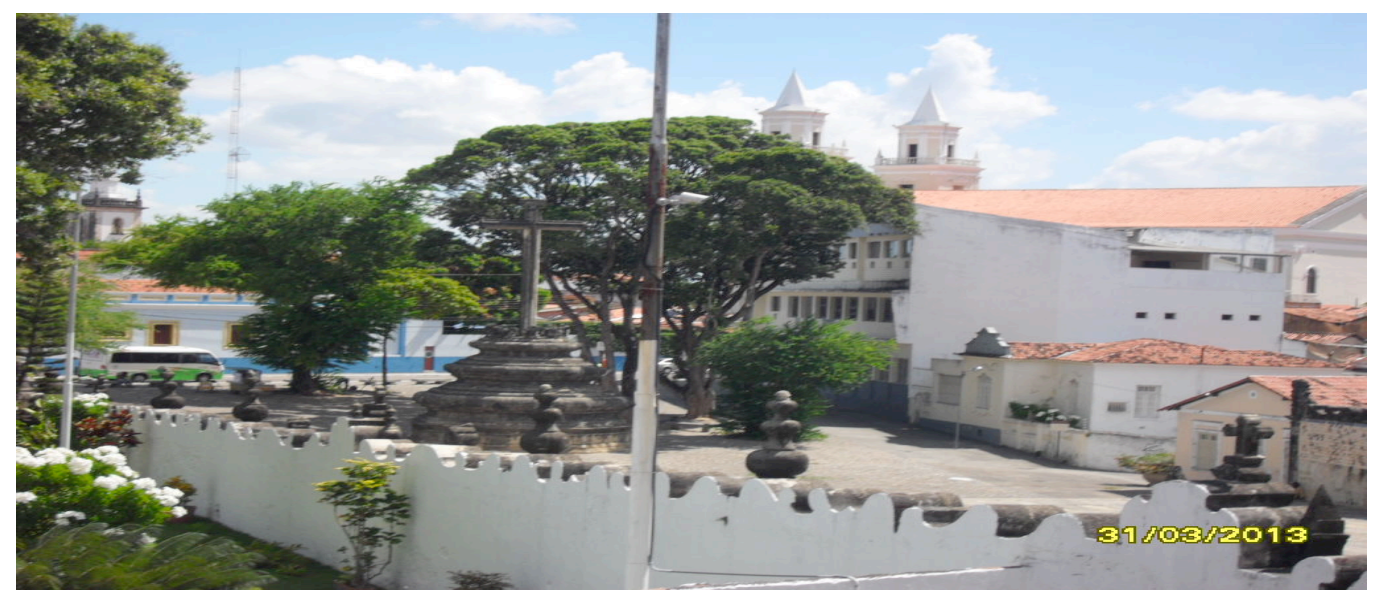

Figura 02 - Fotografia tirada de dentro para fora do Centro Cultural de uma de suas janelas. Ano 2013. Fonte: Georgina Furtado.

Dimas: $O$ sol escaldante aqui no adro impossibilita o nosso trabalho, vamos adoecer assim... Margarida: O monumento parece nos engolir!

Encontrávamos em uma realidade na qual a arte nos museus do Centro Cultural era impossibilitada de se democratizar, de se sociabilizar, pois as relações dos seus públicos com os artefatos artísticos se davam apenas a partir de uma exposição de informações prontas que deveriam ser passadas de uma pessoa à outra, como assim faziam os chamados guias ou mediadores culturais dos museus. Nesta prática realizada nos museus do Centro Cultural, a arte era entendida como um cânone por não oferecer possibilidade aos públicos de se posicionarem a respeito do que viam, mas apenas de aceitarem informações que the eram passadas como uma verdade ou preceito absoluto. 
E a cada experiência de intervenção performática realizada no Centro Cultural a partir das nossas improvisações por entre as salas dos acervos e na interação com os públicos, trazia a sensação e reforçava o entendimento de que o que desejava para o meu trabalho como atriz, professora e pesquisadora, não estava nem nos trabalhos artísticos solitários do museu e nem unicamente fora deles, nos seus públicos. Muito menos nas relações hegemônicas impostas pela instituição, mas estariam nas relações criadas no intermedium destes e que por sua vez tornavam-se pouco a pouco conhecimento.

No Centro Cultural eu e mais quatro atores fomos construindo uma história a partir do que chamamos de "frases geradoras". As "frases geradoras" são frases escritas a partir das imagens dos acervos (esculturas, pinturas, fotografias e instalações) e que envolviam sensações, percepções e sentimentos de cada um dos participantes da pesquisa geridos a partir do contato visual com os artefatos e espaços dos museus. Íamos percebendo que não bastava passar os olhos pelos artefatos como faziam os turistas e estudantes, conduzidos pelos assim chamados guias dos museus do Centro Cultural, mas que era preciso aguçar as percepções do olhar para não apenar ver, mas sentir, perceber o indizível, enxergar o que não podia ser visto.

Uma aproximação com a Cultura Visual onde relatos são produzidos das múltiplas percepções que partem do olhar e geram outras percepções das imagens elaboradas, também paradoxais e contraditórias. As "frases geradoras" pareciam paradoxais quando escritas, por não ser uma tradução do que era visto, mas uma expansão do olhar. Escrevíamos as "frases geradoras" e a partir de improvisações individuais e coletivas íamos desmembrando e combinando as "frases geradoras", transformadas então neste processo, também em frases corporais. Estas frases corporais iam compondo a partir de improvisações realizadas por entre as salas dos acervos e na interação com os públicos dos museus, cenas de intervenção performática.

Fomos a partir deste processo construindo os personagens de uma história que nascia com as artes visuais e desmembravam-se em outros personagens a partir das intervenções performáticas. Por ser a história então originária das experiências de cada um e de todos ao mesmo tempo nas trocas e relações estabelecidas entre os sujeitos e artefatos dos museus e seus públicos, a mesma foi tornando-se o que chamamos de Narrativa, uma composição dramatúrgica híbrida feita do inter-relacionamento entre o teatro, as artes visuais e a literatura. Um processo artesanal de construção que envolvia a interpretação e a construção de sentidos para elaboração de uma história. Se a imagem falasse o que ela diria? Era um mote que nos impulsionava a escrever. 
Contrapondo-se a nossa atuação o trabalho realizado pelos guias dos museus, dava ênfase aos valores e qualidades estéticas e a decodificação dos trabalhos artísticos. 0 artístico a partir do trabalho dos guias era entendido como uma linguagem, como conjunto de sinais e signos que precisavam ser decodificados para serem entendíveis, comunicados e usufruídos como arte. Este fato limitava o artístico a um cânone, uma regra ou preceito com intuito ser repassado a outra pessoa como uma mensagem, uma espécie de alfabetização visual (AGUIRRE, 2007).

Seguindo os propósitos de uma investigação baseada nas artes, em nosso trabalho de intervenção performática, buscávamos um contexto que não estivesse preso ao da obra de arte e seus referenciais simbólicos e semióticos, mas propor-se-ia ir além do seu significante. Partia de um contexto social mais amplo, que ao mesmo tempo transformava e era transformado pelo produto artístico e estava em constante tensão narrativa na interpretação dos seus significados (BARONE, 2003 Apud HERNANDEZ, 2013).

Entendendo o que realizávamos como um ato educativo e de intervenção, havia momentos em que atuávamos dividindo o mesmo espaço com os guias e este fato ressaltava as diferenças entre o que construíamos e o tradicionalmente feito nos museus. Não tendo a intenção de fazer juízos de valor, mas de levantar questionamentos e reflexões pertinentes à pesquisa, citaremos dois momentos:

Em um primeiro momento, por nós vivenciados, os guias descreviam o que existia nas imagens dos acervos, enquanto um menino levantava os braços e incentivava um dos atores que atuando como um dos personagens, um anjo, tentava alçar voo. Os professores que acompanhavam os estudantes exigiam dos alunos a prestarem atenção ao que os guias falavam, enquanto os alunos tentavam interagir conosco. Este fato nos fazia relembrar uma escola e os seus métodos tradicionais de ensino.

Em um segundo momento, uma senhora nos disse: "eu não posso seguir com vocês porque estou do outro lado." Ela conversava como estivesse dentro da Narrativa e trocava ideias e entendimentos sobre o que via e sentia conosco, com os personagens, situando-se na fronteira entre o real e o fictício.

Tomando partido da experiência revelada acima, o que mais importa, parafraseando Hernandez (2013), não é uma habilidade artística e que se reflete nos valores e qualidades estéticas de uma obra de arte, mas o processo dialético, as reações 
originárias da manifestação artística e sua responsabilidade social e como isto transforma a nós mesmos e aos outros, neste processo de interação (HERNANDEZ, 2013).

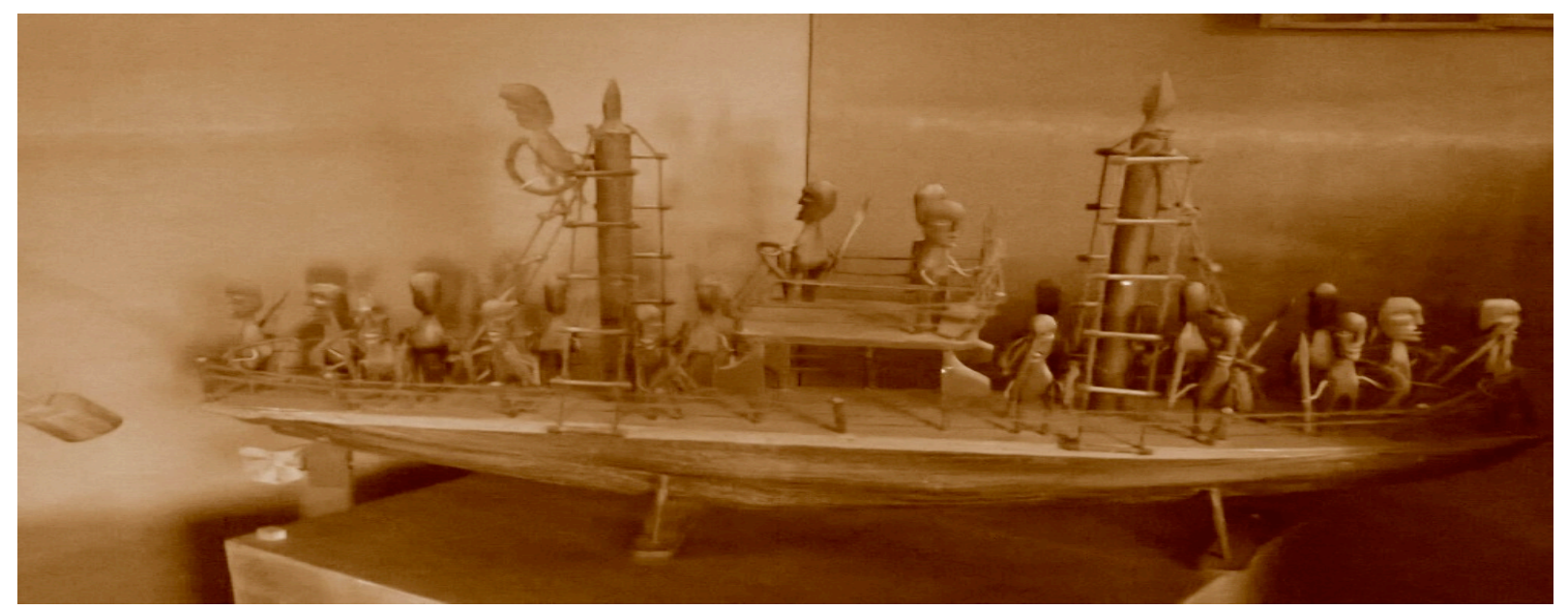

Figura 03 - Centro Cultural. Artefato do museu. Ano 2013. Fonte: Georgina Furtado. Capitão: Içar velas! Trabalhem seu bando de preguiçosos!

Feiticeiro: Eles vieram em grandes navios, acorrentados como animais e eram jogados ao mar! Ao mar!

Se pensarmos em um trabalho artístico numa praça ou numa rua, este pode estar e ser tão preso quanto à liberdade que possa se dar ao mesmo trabalho em um museu ou numa escola. O que importa é aquilo que o mobiliza, nos agenciamentos feitos no e a partir do mesmo em ato criativo e compartilhado, que o tira da sua inercia, nas ações dos sujeitos que dele e a partir do mesmo possam resgatar seu poder de transformar e ser transformado. Desmembrando-se e/ou prolongando-se em novas possibilidades criativas, em um processo contínuo de interpretação e subjetivação. Neste interim, o trabalho artístico precisa "entregar-se", fazer emergir outras leituras, outros entendimentos, outras percepções para além das que já vem com a própria obra dita de autor. Construir possibilidades de subverter limitações impostas ao mesmo e transgredir espaços aparentemente imutáveis. Uma forma de buscar transcender o objeto para indagar as formas de construir sentido (AGUIRRE, 2013).

E foram das experiências vividas nos inter-relacionamentos estabelecidos a partir dos acervos do museu, nos aproximando "do que não vemos" (AGUIRRE, 2013, p.315), que pouco a pouco iam tornando-se sensoriais, performáticas, retornavam a visualidade e permeando-se também com as percepções que emanavam do ato da escrita, que fomos construindo novos contextos e novos sentidos dentro e fora da arte. 


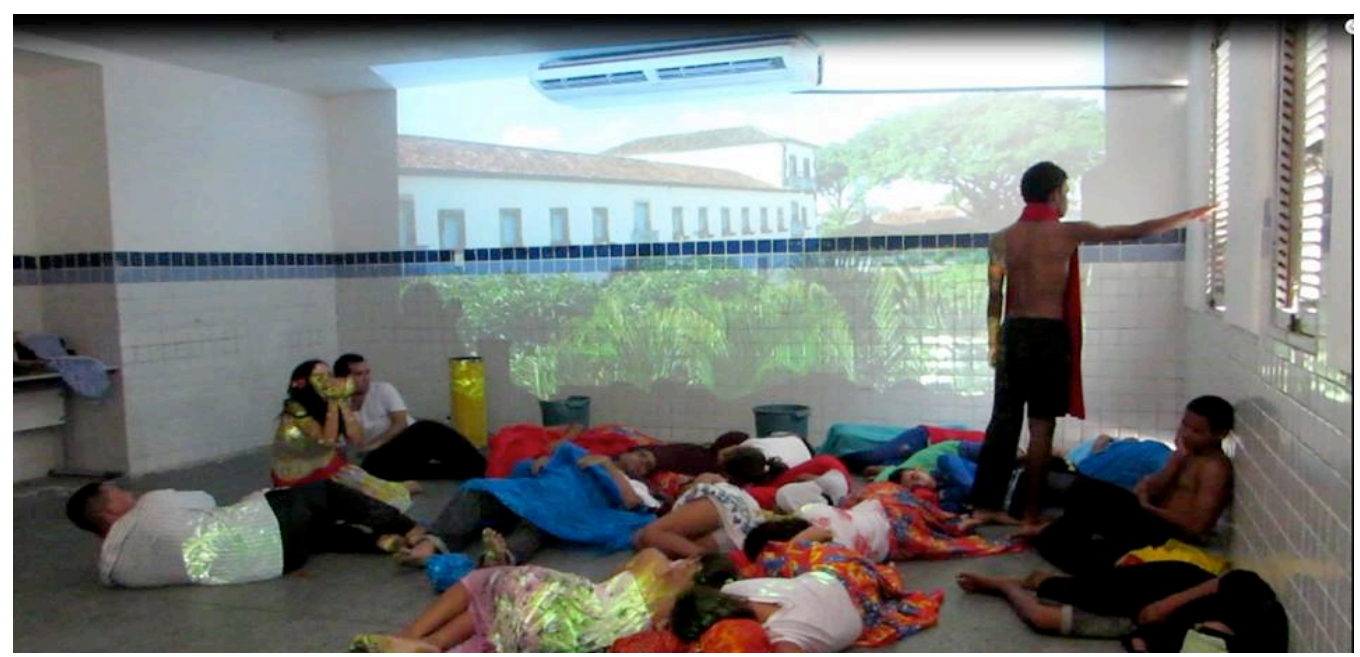

Figura 04 - Escola Municipal. Ano 2013. Fonte: Carlos Cartaxo.

Dama das Flores: Os passarinhos vivem aqui! Livres!

Conta a lenda que quando eles veem as pessoas se juntam a elas E quando bem próximas a elas se grudam ao corpo e as fazem voar! Quem já viu?!

Estas experiências foram se tornando propulsoras de um ato criativo, a construção de uma história que ia assumindo caráter educativo e abria possibilidades para ser trabalhado na escola. Fomos então para a escola levando as imagens dos acervos e a Narrativa, uma história ao mesmo tempo literária e performática composta de cenas que continham as ações e diálogos dos personagens, uma dramaturgia e que como uma obra aberta ia possibilitar o preenchimento de espaços vazios pelos estudantes na construção e reconstrução de personagens e também na elaboração de conceitos, contextos e sentidos da história.

\section{A Experiência e o Processo Narrativo}

Ao longo da nossa investigação, fui percebendo que estávamos aprendendo, atores e estudantes de uma forma diferente. Aprendíamos a partir de uma ficção, ou melhor, de uma construção de histórias que dizia também respeito a nós mesmos, uma Narrativa. Sendo uma narrativa, este ato educativo poderia iniciar assim:

Uma vila de trabalhadores visitada por anjos onde aportam canoas que trazem com elas contadores de histórias.

Nesta vila uma lenda conta que existiu um lugar onde as flores nasciam dos passarinhos...

Seria possível existir um lugar assim? 
Este pequeno trecho diz respeito à pesquisa, as experiências vivenciadas em um Centro Cultural e em uma escola pública municipal e transformaram-se em outros contextos e sentidos na busca da construção do conhecimento.

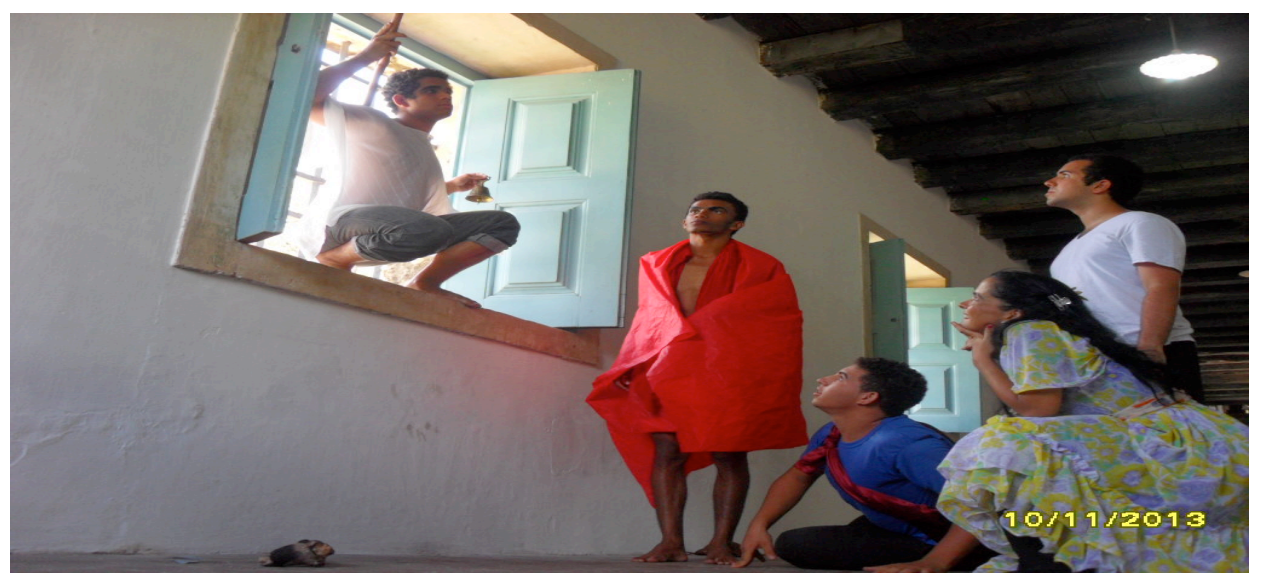

Figura 05 - Centro Cultural. Ano 2013. Fonte: Edinaldo Silva.

Anjo: Os passarinhos são as chaves de onde eu vim.

Segundo Walter Benjamin (1992) uma narrativa não é nada mais, nem nada menos, do que conselhos tecidos da própria vida e na própria vida, nasce da experiência do próprio narrador e dos seus ouvintes; são incorporados à história contada e não tem intenção de responder a perguntas ou dar explicações e informações prontas e pré-concebidas sobre algo, pois a comunicação aconteceria não no ato de transmissão de uma mensagem, mas na sugestão de continuação de uma história; quando aprendendo a contá-la, aprende-se com ela. Algo como uma espécie de sabedoria, artesanal, que nasce das coisas imersas no mundo e do modo de relacionar-se e conviver com elas. O narrador seria aquele que sabe dar conselhos. A ficção surge com a narrativa e com ela, os contadores de histórias.

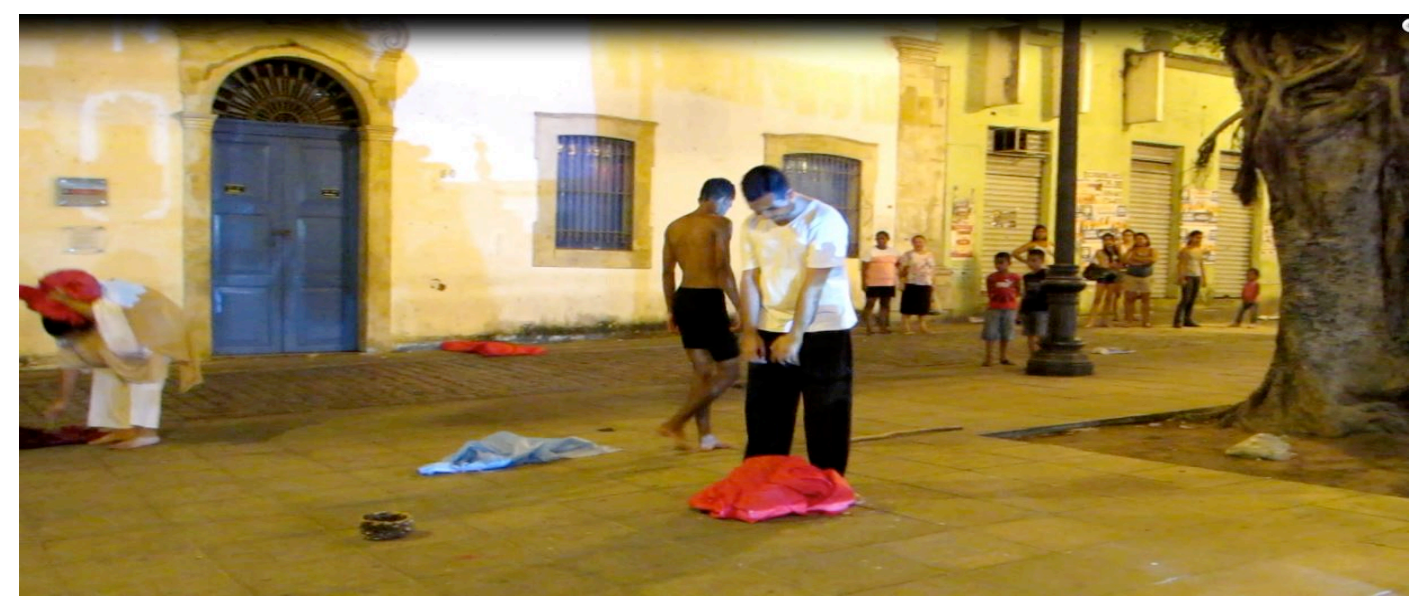


Figura.06 - Imagem editada por Georgina Furtado de vídeo. Performance na praça Rio Branco, João Pessoa, Paraíba, Brasil. Ano 2013.

Fonte: Carlos Cartaxo.

Miguel: Hoje é um dia especial, um dia que não diz respeito ao hoje, mas que vem do passado!

Dimas: E com vocês e a partir de vocês como um barco à deriva será levado ao longe!

Margarida: Uma canoa sem destino certo...

Henrique: Mas não tomem por nada justo. Só são traços. Que assim como as nossas vidas, com o passar dos dedos se apagam.

Ivan: E outros virão e construirão outros rascunhos... Mas de uma forma ou de outra estaremos lá. Algum dia...

Venham!

Sendo o ato criativo uma Narrativa, os autores da história, são os protagonistas da história contada, mesmo sendo esta uma ficção. Eles são personagens criados dentro da história baseados nas próprias experiências vividas na construção desta história. Fazer da experiência de intervenção performática uma Narrativa significa construir uma história onde os personagens, atores e estudantes dentro do mesmo processo de criação estejam presentes e interagindo de forma literária e performática na construção da história.

Então os conflitos, as dificuldades, as impossibilidades, mas também as potencialidades e questionamentos do processo criativo envolvendo os atores e estudantes estão presentes na história concomitantemente aos conflitos dos personagens e sua elaboração dentro da escrita ficcional. Este é o objetivo fundamental da referida tese de doutorado, construir de uma experiência de intervenção performática uma proposta dramatúrgica híbrida, uma matriz pedagógica para o ensino da arte, uma Narrativa, reflexiva e crítica com suas conexões com a vida e as coisas do mundo na construção do conhecimento. Assim retornamos com a questão da nossa investigação: Como fazer de uma dramaturgia e sua construção, imersa no espaço público, das relações estabelecidas política, socialmente e culturalmente entre os sujeitos e o espaço, outra possibilidade para o ensino da arte, com conteúdos próprios para serem trabalhados em processo de ensino-aprendizagem?

A nossa investigação constituindo-se do inter-relacionamento entre o teatro, as artes Visuais e a literatura é uma tentativa de abolir com o que conhecemos como "transmissão de conhecimentos" vista como uma via de mão única. Ou seja, em que uma pessoa transmite o que sabe a outra e esta apenas recebe uma informação, não recebendo abertura ou possibilidades de posicionar-se ou questionar e discordar sobre o 
que Ihe está sendo oferecido como conhecimento. Em busca de outra "narrativa" e que possa ser utilizada para o ensino da arte, a nossa proposta é que este conhecimento seja colocado em causa e que possa dar impulso à construção de outro tipo de conhecimento derivado da experiência (Eisner, 1998 Apud Hernandez, 2013).

No Centro Cultural cada um dos colaboradores da pesquisa teve a possibilidade de se posicionar frente aos trabalhos artísticos e sem abrir mão dos seus valores socioculturais, mas pelo contrário, estes valores são protagonizados em cena pelos personagens e na elaboração dos contextos e sentidos, portanto das experiências de cada um e das relações criadas entre todos na elaboração da história. Como dizia respeito às experiências e valores de cada um, fomos construindo um trabalho que cada vez mais se aproximava da vida e das coisas relacionadas ao mundo e dessacralizando a obra de arte que passava a adquirir outros desmembramentos na construção do conhecimento e não na transmissão de um conhecimento.

Ao longo da experiência de intervenção performática os trabalhos artísticos ganham uma nova vida e nos faz levantar questões sobre as próprias imagens elaboradas, múltiplas, muitas vezes contraditórias e controversas a partir do nosso próprio corpo em ação. Os alunos e nós atores aprendemos a questionar a vida e as coisas do mundo fazendo arte, do ato do aprender a contar uma história e é do construir desta história, das percepções de cada um e das trocas vivenciadas dentro do processo criativo que o conhecimento é elaborado.

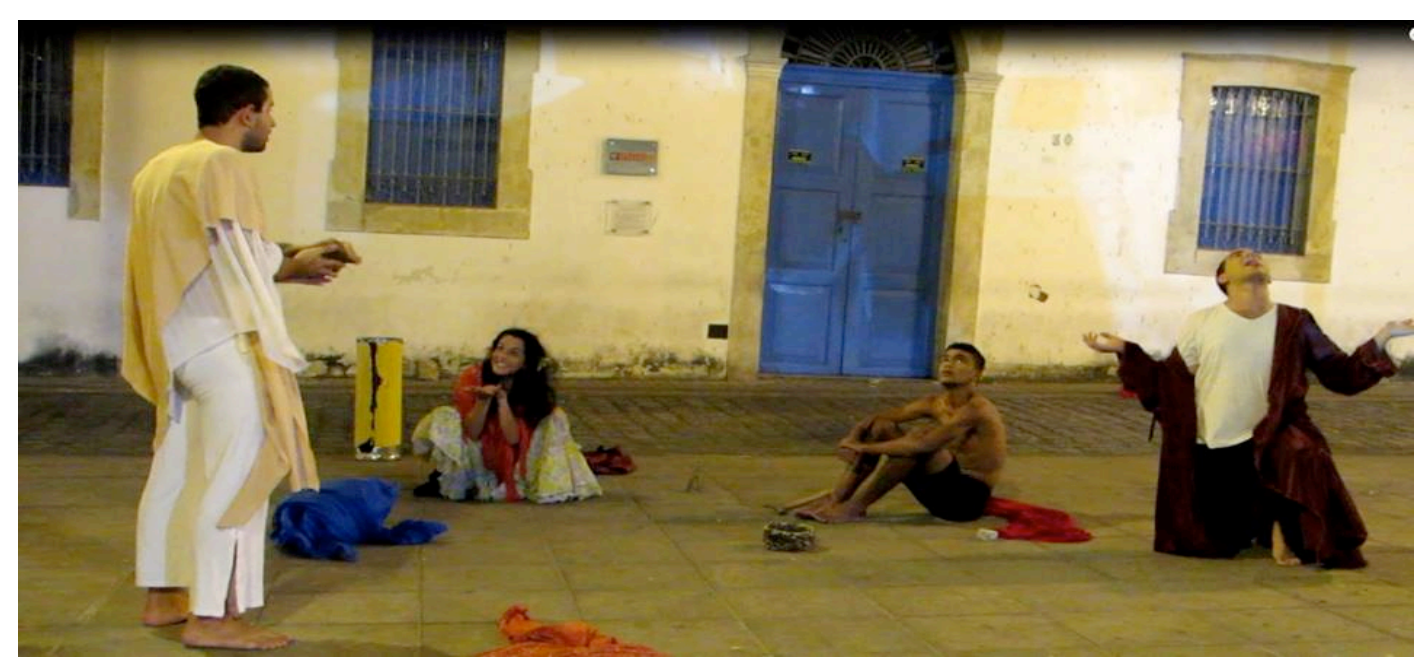

Figura 07 - Imagem capturada por Georgina Furtado de vídeo. Performance na praça Rio Branco, João Pessoa, Paraíba, Brasil. Ano 2013. Fonte: Carlos Cartaxo.

Madalena: João a garoa tá caindo. É chuva João!

Depois de todos estes anos! 
A Narrativa, o objeto de pesquisa, vai sendo construída ao longo da busca de elaboração de sentidos intrínsecos à própria Narrativa. É na busca pela elaboração de sentidos, nas questões, nos conflitos, nas dúvidas, nos acertos e desacertos, nas reflexões críticas ao longo da construção da história contada, que o objeto de pesquisa vai sendo elaborado.

Referir-se à elaboração de sentidos é referir-se à atuação e interpretação dos sujeitos, atores e estudantes, que participam de forma ativa nesta experiência e seus interrelacionamentos com os trabalhos artísticos. E paralelamente a isto, a construção de outros contextos que se entrelaçam com os aspectos sociais e políticos que dizem respeito ao contexto físico de onde vem sendo elaborada a intervenção e afetada por este.

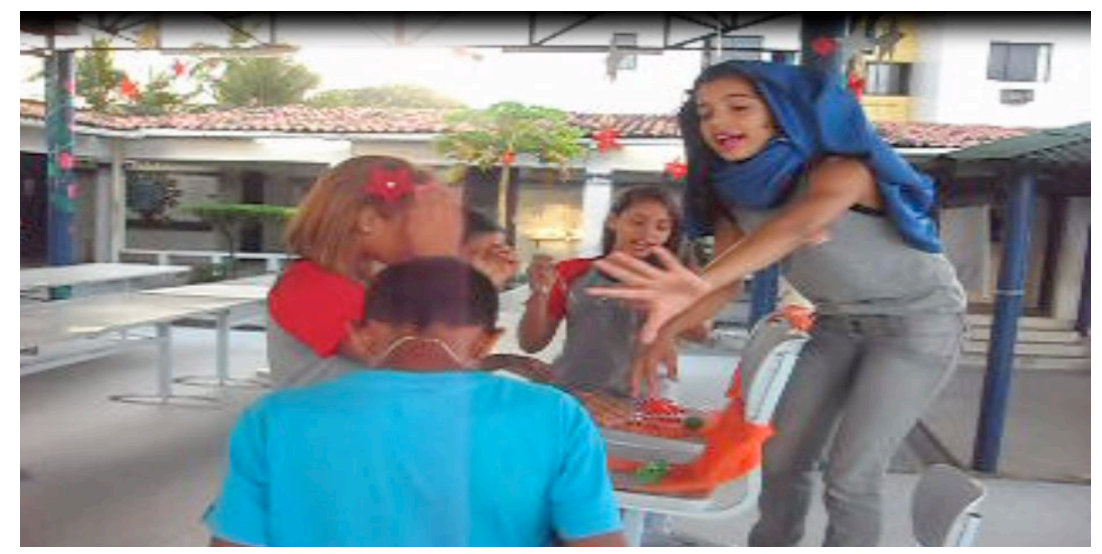

Figura.09 - Imagem capturada por Georgina Furtado de vídeo. Filmagem feita por Rafael, um dos nossos alunos na escola pública municipal.

Ano 2013.

Dona Xepa: Vamos lá minha gente!! Tudo aqui a preço de banana!!

Sendo assim, fui descobrindo ao longo do desenvolvimento da pesquisa de tese, que uma escultura pode ser tão teatral quanto uma performance; e por sua vez que, de um ato performático podem emanar visualidades cuja força imagética pode ser tão sensorial quanto a real atuação de atores em cena. O mesmo aconteceria com a literatura cuja escrita vai tornando-se sensorial, visual e auditiva nos seus inter-relacionamentos com as imagens das experiências vivenciadas e possibilitando o desmembramento para outros campos disciplinares. As experiências vivenciadas, aliadas à construção de um pensamento crítico sobre elas a partir da Narrativa foram se configurando como uma prática de investigação baseada nas artes e mais propriamente a/r/tográfica, uma Pesquisa Educacional Baseada em Arte - A/r/tografia. 


\section{O Caminho Metodológico}

Aprendendo a aprender a contar uma história, a Narrativa vai sendo composta dos interrelacionamentos e das questões e debates que dela emana. Uma escrita ao mesmo tempo visual, performática e literária e que levanta questões políticas, sociais do contexto em que está inserida e do contato com outros contextos construídos e também reelaborados. O que para o ensino da arte na escola, passa-se a obter com a Narrativa, uma escrita que pode dizer respeito a cada um dos envolvidos no processo de aprendizagem e a todos ao mesmo tempo. Também aliados a seus aspectos sociais e políticos dentro e fora da instituição, já que os valores sociais de cada um dos envolvidos poderão estar presentes na narrativa. Uma possibilidade de escrita e de se conectar com o mundo onde todos participam e aprendem com ele.

Esta busca pela escrita é o reencontro com as questões: Como um processo criativo e dramatúrgico pode levar a uma melhor compreensão do mundo e mobilizar debates e reflexões críticas sobre aspectos sociais, culturais e políticos dos sujeitos envolvidos e seus contextos? Ou mais especificamente: Como construir de uma experiência de intervenção performática uma dramaturgia para o ensino da arte? Como questionar e refletir sobre o meu próprio papel como pesquisadora, atriz, professora e levantar questões e possibilidades para outro tipo de prática pedagógica, para além da tradicionalmente aceita em nossas escolas?

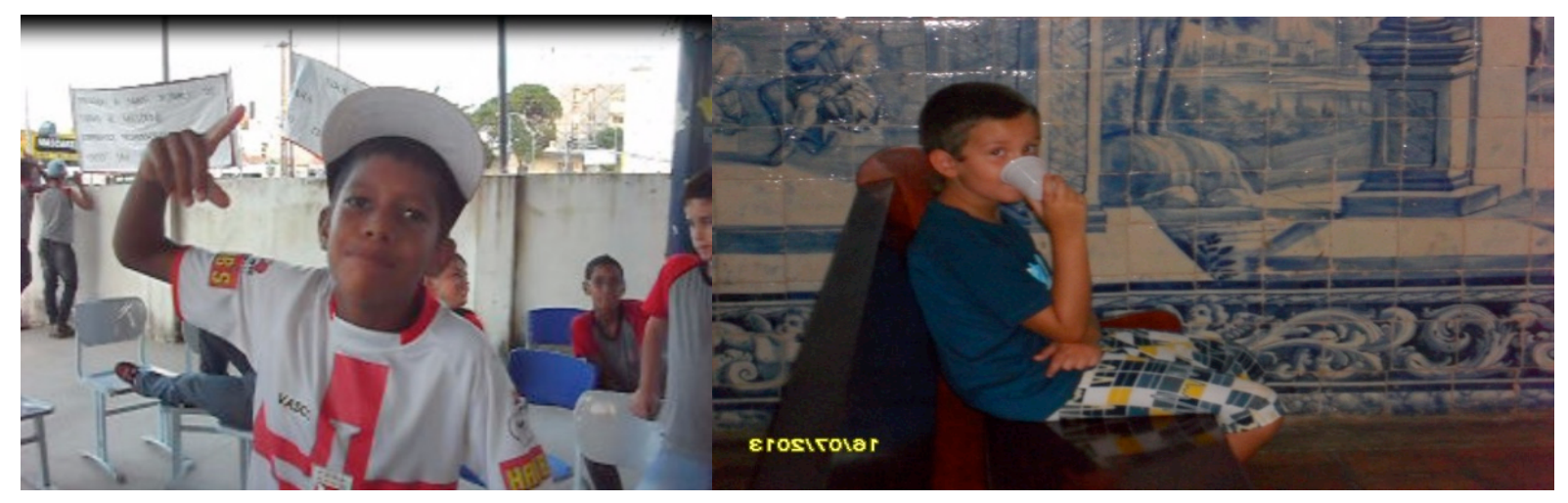

Figura.10 - Imagem capturada por Georgina Furtado de vídeo. A primeira filmagem, da esquerda para direita, foi feita por nosso aluno Rafael na escola pública municipal e a segunda pelo ator Moisés de Pia, no Centro Cultural. Ano 2013.

Um olhar, uma voz, que não se intimida, daquele que se apodera, se legitima:

"Meu nome é Everton! Escolhi a imagem da mulher que transporta um pote de água no rio e a transformei...". 
Ao estudarmos os trabalhos realizados e organizados em coletânea por Belidson Dias (2013) e Rita L. Irwin (2013) em livro homônimo de sua autoria, encontramos referenciais teóricos e práticos que se identificam com a nossa pesquisa e que desta forma, justificam a construção do processo metodológico em questão.

A pesquisa a/r/tográfica, ao contrário da pesquisa tradicional, positivista, é um ato criativo em si e per si, baseando-se no conceito de que o sentido não é encontrado, mas construído. E que o ato da interpretação construtiva é um evento criativo, promotor de múltiplos níveis de envolvimento; tanto cognitivos como emocionais. Deste modo o sujeito é elemento fundamental seja no seu posicionamento e envolvimento no processo criativo bem como na compreensão e leituras sobre o contexto ou contextos em que esteja inserido (Dias, 2013).

Segundo Belidson Dias (2013) "o ponto crítico da $a / r /$ tografia é saber como desenvolvemos inter-relações entre o fazer artístico e a compreensão do conhecimento" (DIAS, 2013:24). Conforme a própria sigla da palavra "a/r/tografia" constituída de maneira metafórica A/R/T: Artist (artista), Researcher (pesquisador), Teacher (professor) e graph (grafia:escrita/representação), a pesquisa a/r/tográfica seria a fusão destes papéis, o artista, o pesquisador e o professor em um só sujeito.

Em nossa pesquisa seria também acrescentar os alunos como sujeitos ativos, protagonistas no processo de construção do conhecimento, já que os mesmos estão imersos na vivencia de uma experiência, são os personagens da história contada e constituem o próprio ato criativo e não externos a ele. Uma ação educativa realizada em ato partilhado e compartilhado.

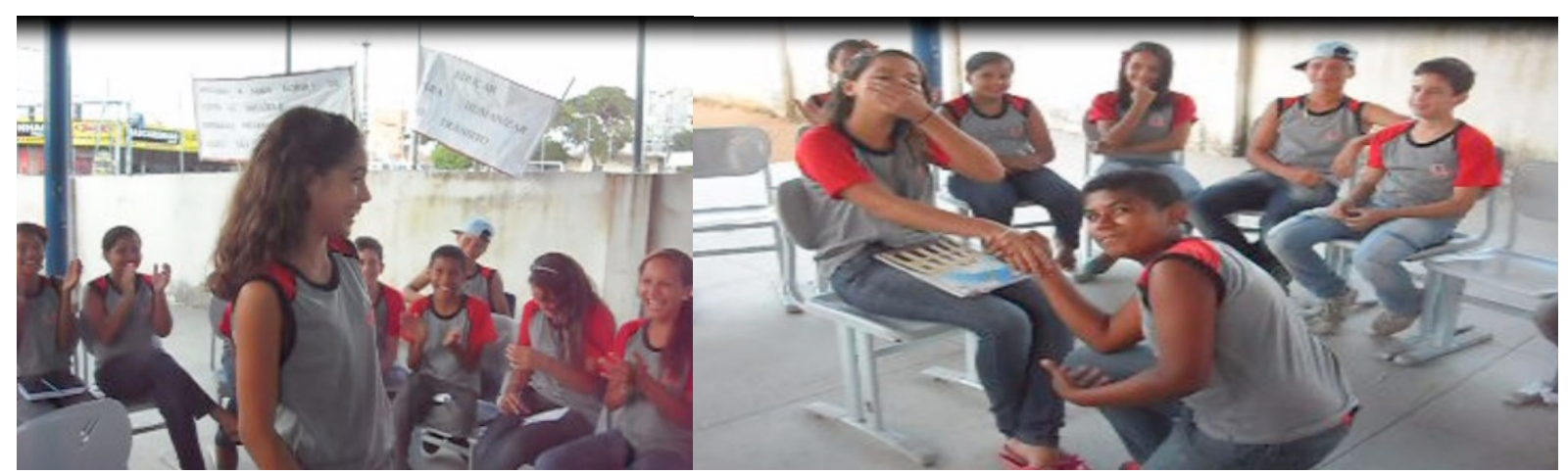

Figura 11 - Imagem capturada por Georgina Furtado de vídeo. A primeira filmagem, da esquerda para direita, foi feita por nosso aluno Emerson e a segunda por Rafael, ambas na escola pública municipal. Ano 2013. 
Ele não saiu na primeira foto, mas das suas mãos ficaram registrados os sorrisos de todos. Certo dia, a diretora me chamou em um canto do salão e disse: "Não coloque João para participar com os outros, ele não presta atenção em nenhuma das aulas e só iria atrapalhar".

Mas além de participativo, João tornou-se um dos nossos cinegrafistas e até pediu a mão daquela que admirava. E todos o incentivaram:

Vai João!! Vai!!

E poderia ter-Ihe dito: Você não queimou o filme João como disse.

Você o produziu!!

Sendo a a/r/tografia "uma forma de representação que privilegia tanto o texto escrito como a imagem visual quando eles se encontram em momento de mestiçagem ou hibridização" (DIAS, 2013, p.25) o nosso objeto de estudo, a Narrativa, torna-se uma constante elaboração relacionada de tempos e espaços liminares, terceiros espaços, entre-lugares. Parafraseando Dias (2013), "o artógrafo busca o diálogo, a mediação e a conversação" uma maneira evocativa de produzir saberes que os formatos tradicionais de pesquisa já não são mais possíveis de atender (DIAS, 2013, p.25).

\section{A Narrativa e O Modelo de Ação Dramatúrgica}

Como proposta para ser usada tanto no ensino formal quanto no informal de arte, a Narrativa amalgama duas camadas dramatúrgicas, como possível modelo de ação educativa a ser utilizada e que contem os conteúdos que foram construídos ao longo do processo investigativo e que por sua vez, também é dramatúrgico. Entre os conteúdos construídos ao longo da investigação podemos citar: a frase narrativo-geradora, o desenho-narrativo, o passeio-narrativo, a micro narrativa oral, a micro narrativa escrita, a improvisação-narrativa, o debate-narrativo, a intervenção narrativo-performática, a intervenção-silenciosa, a pesquisa do entorno/cotidiano e as conexões narrativas. As duas camadas dramatúrgicas constituem o que chamamos de Narrativa, uma proposta híbrida para o ensino da arte.

Uma das camadas contém o desenrolar de todo o processo dramatúrgico, quando alunos e professores a partir das etapas de elaboração da dramaturgia vão revendo a partir desta camada (uma escrita dramatúrgica que revela o processo de construção de uma história) sua prática também como um processo investigativo ainda em construção. Assim torna-se possível nesta camada a revisão, alteração e transformação de conteúdos, bem como acréscimos de outros que possam surgir a partir da interação entre alunos e professores com o espaço público. Um trabalho compartilhado para construção do conhecimento. 
Os personagens desta camada dramatúrgica são os alunos e professores, bem como aqueles que interferiram e contribuíram para desenvolver a dramaturgia, o que inclui as suas potencialidades e impossibilidades, os entraves e problemas encontrados ao longo do processo de construção dramatúrgica e também as dúvidas, questionamentos e reflexões críticas que foram surgindo ao longo desta construção imersa no espaço público.

A outra camada é o transcorrer da dramaturgia não a partir do seu processo de construção, mas como um acontecimento, com enredo que vai sendo construído pelos alunos e professores e que transcorre ao longo da escrita dramatúrgica, cena por cena, entremeados à construção da camada anterior. Um processo de aprendizagem que antes de tudo é aventura, descoberta de si mesmo em um processo criativo que falando a partir de cada um, fala a partir de todos, de contextos e aspectos, sociais, culturais e políticos em relação, como uma busca e encontro por caminhos ainda desconhecidos. Os personagens desta camada são os professores e alunos que aqui assumem o papel de outros personagens como forma transgressora de ultrapassar as limitações e impedimentos encontrados na camada anterior de construção. São personagens criados a partir da imaginação do aluno e que pode ao longo do processo da escrita dramatúrgica fazê-lo ver a partir da sua construção, o invisível, a partir de um gesto por ele construído que seja capaz de inscrevê-lo como sujeito do processo de ensino-aprendizagem e construtor da sua própria história.

Abaixo, descreveremos o processo investigativo e as camadas dramatúrgicas que ao longo da investigação foram sendo promotoras dos conteúdos do processo de ensinoaprendizagem, bem como do modelo de ação dramatúrgica. Neste trabalho não explanaremos os conteúdos deixando para a escritura da tese este encargo, já que partimos do entendimento que os mesmos não devam se esgotar em si mesmos, mas estarem disponíveis a possíveis desmembramentos e transformações na interação com nossos leitores. E assim, como uma narrativa que não faz do seu fim um ponto final, que este seja apenas um ponto de partida para construção de outras histórias a partir desta.

\section{O Processo Investigativo e as Camadas Dramatúrgicas}

A investigação é composta de duas etapas que se coadunam em um processo criativo e dramatúrgico como proposta para o ensino da arte, que chamamos de Narrativa. A primeira etapa da investigação foi realizada a partir de uma experiência de intervenção performática em um Centro Cultural e em uma escola pública municipal. O que unificou os dois contextos diferenciados foi ação educativa realizada a partir da construção de 
uma história tanto performática quanto literária, conforme descrevemos nas etapas acima, a partir das inter-relações estabelecidas entre os sujeitos da pesquisa, a pesquisadora e seus colaboradores (atores e estudantes), os trabalhos artísticos do Centro Cultural (pinturas, esculturas e fotografias), os públicos dos acervos do Centro Cultural, bem como os aspectos sociais e políticos que envolviam estes contextos e que afetavam diretamente e indiretamente, a construção da história. Configurou-se assim, como um processo autoetnográfico em que sujeito e objeto estão dissolvidos em um único corpo investigativo. Os sujeitos desta etapa da investigação são: cinco atores incluindo a mim como atriz e pesquisadora, os públicos do Centro Cultural e vinte e quatro alunos de uma escola pública municipal, os quais vinte e um deles alunos do 70 ano do ensino fundamental e três deles, alunos do $8^{\circ}$ ano do ensino fundamental.

A segunda etapa da investigação é a escrita da tese e esta é composta de duas camadas dramatúrgicas que se entrelaçam ao longo da investigação: I camada - Centro Cultural e Escola - A Busca por uma Matriz Pedagógica para o Ensino da Arte: Esta camada dramatúrgica consiste no desenrolar do processo investigativo no Centro Cultural e na escola pública municipal em busca da construção de uma história tanto performática quanto literária e que possa tornar-se uma matriz pedagógica para o ensino da arte. Os personagens nesta etapa da investigação são os personagens da primeira etapa (atores, estudantes e públicos dos acervos do Centro Cultural) transformados e desmembrados em outros personagens como forma de abarcar os propósitos investigativos em seus aspectos políticos, sociais e ideológicos.

Sendo assim, podemos encontrar nesta primeira camada dramatúrgica entre os personagens, além de uma pesquisadora e seus colaboradores e os públicos do Centro Cultural, uma bailarina, um músico, um admirador de arte e uma vendedora de cocos. 0 núcleo de ação dramatúrgica se dá a partir de forças contrárias que interagem na busca por superação. De um lado, a pesquisadora e seus colaboradores e alunos da escola pública municipal, do outro, o poder hegemônico do Centro Cultural representado pelo corporativismo dos guias dos acervos e pela igreja, cujo domínio na direção do Centro se impõe em uma censura manifesta às atuações performáticas do grupo.

II camada - A Cabana e os Professores e Alunos Contadores de Histórias: Esta camada dramatúrgica é uma tentativa de romper com as limitações impostas ao grupo ao longo do processo investigativo e que foi revelado na I camada dramatúrgica. Sendo assim, nesta segunda camada elaboraram-se reflexões críticas sobre a construção de uma concepção de escola diferente que chamamos de Cabana. Nesta camada busca-se atender aos propósitos investigativos, que são também educativos e pedagógicos, como 
a construção de conteúdos próprios para serem trabalhados em processos de ensinoaprendizagem em arte e que se completam também com os conteúdos construídos na I camada dramatúrgica.

Nesta segunda camada dramatúrgica a história que na I camada está em processo de construção pelo grupo, nesta segunda camada já está concluída e vai decorrendo como um acontecimento, revelando cena por cena ao leitor os personagens que foram construídos pelo grupo na I camada a partir dos inter-relacionamentos entre os sujeitos, pesquisadora e colaboradores, públicos do Centro, alunos e trabalhos artísticos. Estes personagens embora transformados e desmembrados em outros a partir dos da I camada dramatúrgica, não deixam de guardar relações com os anteriores.

Podemos assim, então encontrar os seguintes personagens nesta segunda camada dramatúrgica: cinco professores de teatro, treze alunos nos quais cinco deles são adultos, agricultores, pescadores, comerciantes, artesãos, vendedoras de frutas, um mendigo, os públicos das intervenções performáticas nas ruas e praças da vila, visitantes de um ponto turístico chamado Pé de Tamarindo (árvore), um sacristão, um padre, um seminarista, um funcionário escravo da igreja, uma funcionária escrava da igreja, um feiticeiro, um radialista e moradores de uma Casa de Repouso.

Os personagens desta segunda camada se relacionam em sua construção dramatúrgica com os personagens da primeira camada, mas transformam-se para além deles em outros personagens, como atitude também de transgressão frente à censura e as impossibilidades encontradas na camada anterior. O núcleo de ação dramatúrgica então se dá com professores que se autodenominam construtores de sentidos e que desembarcando em uma vila em um barco buscam realizar um trabalho educativo diferente em uma escola chamada de Cabana. Lá eles almejam construir conhecimento através da arte e no seu inter-relacionamento dos sujeitos com o espaço público. Representam a resistência em relação a forças cuja hegemonia opõe-se à ação do grupo, como a igreja e a escola tradicional.

Destes conflitos surgem ações que inseridas no contexto da vila e da vida dos seus habitantes, fazem com que professores e alunos transformem a busca por superação dos problemas dos quais estão envolvidos e dos quais fazem parte, força propulsora para alcançar os seus objetivos que além de individuais são também coletivos. Os conteúdos da matriz pedagógica então vão sendo construídos pelos próprios personagens que vão ganhando autonomia ao longo da escrita, ao mesmo tempo investigativa e dramatúrgica. 


\section{Considerações Finais}

Para o ensino da arte as camadas dramatúrgicas como proposta educativa, vão ao longo do processo criativo dando ênfase ao trabalho compartilhado de ensino-aprendizagem, em que alunos e professores aprendem juntos construindo uma história ao mesmo tempo individual e coletiva e que diz respeito aos aspectos sociais, culturais e políticos nos quais estão inseridos. Os conteúdos não são ausentes da realidade dos alunos e seus contextos, mas fazem dos mesmos, elementos fundamentais do ato pedagógico e educativo.

Também fazendo uma abstração da I camada dramatúrgica à ação educativa em uma escola, queremos ressaltar a importância dos professores de assumirem uma atitude de reflexão crítica sobre as suas práticas, dos seus métodos, para assim manterem os seus conteúdos vivos e em constante transformação, possibilitando e incluindo também a participação dos alunos neste processo. Se por um lado, temos como na II camada dramatúrgica a aplicação dos conteúdos que serão trabalhados em processos de ensinoaprendizagem, do outro, na primeira camada, mas relacionando-se à II camada, temos a reflexão e avaliação sobre o que está sendo construído como conhecimento e que não diz respeito apenas aos alunos, mas também aos professores e todo o contexto educativo e social dos quais fazem parte.

Na história ficcional ouvem-se gritos que ressoam de navios negreiros ou se é levado a uma vila de trabalhadores visitada por anjos. Nesta vila uma lenda conta que existia um lugar onde as flores nasciam dos passarinhos...seria possível criar este mundo que não existe? Segundo os participantes do processo, Sim! Com a ajuda de todos. Porque segundo a personagem Eva : "a força das palavras talvez esteja em não emiti-las. Mas em senti-las!".

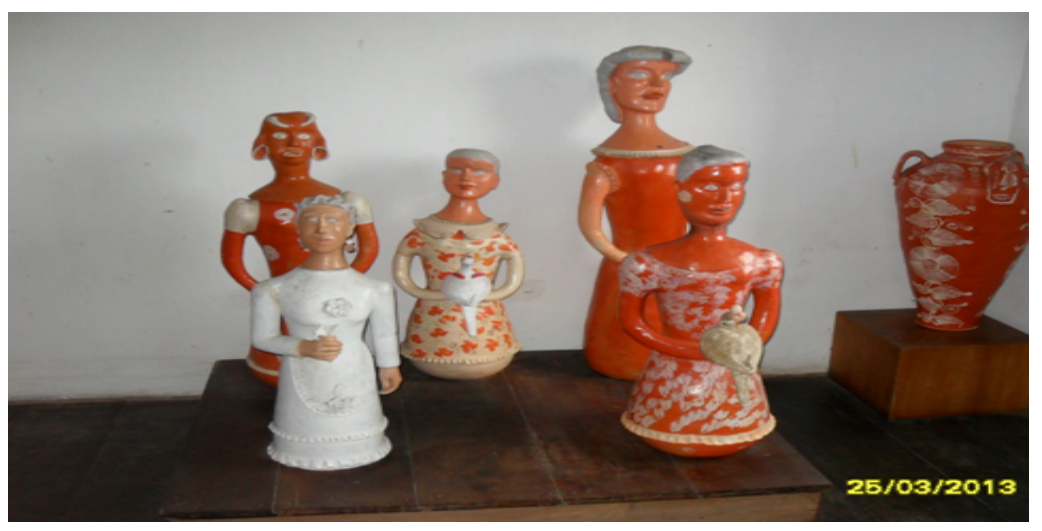

Figura 12 - Centro Cultural São Francisco. Peças do Acervo do museu. Ano 2013. Fonte: Georgina Furtado. 
Feiticeiro: Bouquet de flores no campo ainda nos farar voar!

Uma experiência de intervenção performática sob estas perspectivas, como uma narrativa, é considerar no âmbito educativo os sujeitos envolvidos no ato criativo, estudantes e professores, como protagonistas do processo de aprendizagem. Também uma possibilidade de compreensão do contexto existente ou contextos elaborados a partir da construção de sentidos ao longo de uma construção de histórias. O aluno dá sentido ao seu aprendizado, apodera-se do que está aprendendo e do sentido elaborado constrói conhecimento.

O objeto de estudo da pesquisa, a Narrativa, como uma quarta dimensão de escrita, portanto, artográfica, também é uma maneira de criação literária diferenciada, onde cada um pode construir seus próprios relatos e abre possibilidades para que outros leitores possam se colocar dentro da experiência a partir das múltiplas interpretações elaboradas ao longo da narrativa. O meu trabalho como artista, pesquisadora, professora, funde-se e confunde-se em busca do apoderamento desta escrita, uma experiência una e ao mesmo tempo coletiva de aprender a aprender, mas também de desaprender e reaprender de maneira partilhada e compartilhada imersos em uma ficção e no entremear da construção e contação de uma história.

Sendo assim, as duas camadas dramatúrgicas constituem uma única dramaturgia que chamamos de Narrativa, que se realiza em um transpassar de tempos e espaços, no limiar entre o real e o imaginário, pois vai sendo construída da experiência, e assim está em constante processo de metamorfose (BLANCHOT, 2005). As duas camadas se completam, mas não se ilustram, e seguem construindo um espaço relacional que é o próprio processo de ensino-aprendizagem.

Os alunos vão então aprendendo juntamente com os seus professores a construírem uma dramaturgia cujos conteúdos têm seus elementos constituintes originários do contexto social e cultural dos quais fazem parte, bem como do contexto educativo no qual está inserido. A Narrativa vai tornando-se a voz do aluno, o gesto invisível, do que nos fala Agamben (2007), que nega a si mesmo quando está prestes a dizer o que não consegue ser dito. E por isso prolonga-se ao infinito, formando uma corrente que busca encontrarse.

\section{Referências}

AGAMBEN, Giorgio. O Autor como gesto. In: Profanações. São Paulo: Boitempo, 2007. 
AGUIRRE, I. Teorías y prácticas en Educación Artística. Navarra: Octaedro/EUB, 2007.

AGUIRRE, I. Reflexividade e desafios na pesquisa com jovens produtores de cultura visual. In. MARTINS, R.; TOURINHO, I. (Orgs.). Processos e Práticas de Pesquisa em Cultura Visual e Educação. Santa Maria: Ed. da UFSM, 2013. p. 291-320.

BENJAMIN, W. O Narrador. In: Sobre Arte, Técnica, Linguagem e Política. Lisboa: Relógio D’Água, 1992.

Brasil. Secretaria de Educação Fundamental. Parâmetros curriculares nacionais: Arte Secretaria de Educação Fundamental. - Brasília:MEC/SEF, 1998.

DERRIDA, Jacques. Gramatologia. Trad. Mirian Chnaiderman e Renato Janine Ribeiro.

São Paulo: Perspectiva, 1999.

DIAS, B. A/r/tografia como Metodologia e Pedagogia em Artes: uma introdução. In. DIAS, B.; IRWIN, R. (Org.). Pesquisa Educacional Baseada em arte: a/r/tografia. Santa Maria: Ed. da UFSM, 2013. p. 21-26.

HERNÁNDEZ, F. A pesquisa baseada nas artes: propostas para repensar a pesquisa educativa. In. DIAS, B.; IRWIN, R. (Org.). Pesquisa Educacional Baseada em arte: a/r/tografia. Santa Maria: Ed. da UFSM, 2013. p. 39-62.

IRWIN, R. A/r/tografia. In. DIAS, B.; IRWIN, R. (Orgs.). Pesquisa Educacional Baseada em arte: a/r/tografia. Santa Maria: Ed. da UFSM, 2013. p. 27-35.

IRWIN, R. A/r/tografia: uma mestiçagem metonímica. In. DIAS, B.; IRWIN, R. (Org.). Pesquisa Educacional Baseada em arte: a/r/tografia. Santa Maria: Ed. da UFSM, 2013. p. 125-135.

RANCIÈRE, Jacques. O Mestre Ignorante: cinco lições sobre emancipação intelectual. Mangualde: Editora Pedagogo, 2010.

\footnotetext{
i Doutoranda em Educação Artística da Faculdade de Belas Artes da Universidade do Porto, Portugal. E.mail: georginafurtado@uol.com.br

Recebido em 30/05/2014

Aprovado em 15/12/2014
} 